\title{
田畑伸一郎，末澤恵美編『CIS: 旧ソ連空間の再編成』
}

(国際書院，2004 年)

\author{
大 中 真 \\ (桜美林大学国際学部専任講師)
}

\section{Shinichiro TABATA, Megumi SUEZAWA, eds., The CIS: Restructuring of Former Soviet Spaces}

(Tokyo: Kokusai Shoin, 2004)

\author{
ONAKA, Makoto \\ Lecturer, Obirin University
}

1991 年 12 月のある日, まだ大学生であった評者は, 調べ物のために東京の国立国会図書館
を訪れていた。昼食を取るために階上の食堂へ行くと, テレビでは臨時ニュースが流され, 人 だかりが出来ていた。それこそ，ソ連邦の解体とCIS（独立国家共同体）の結成を宣言したべ ロヴェージ協定を伝える速報であった。既に東欧革命, ドィッ統一，8月クーデタ事件を経験 していた世界にとっても，衝撃的な出来事だったことは間違いない。国会図書館内といら場所 を考慮に入れても，速報を見ていた人々は何も言わず，黙って深刻に画面を眺めていた光景 を，評者は昨日のことのように鮮明に覚えている。

この CIS 誕生からの軌跡 10 年を総括し，「CIS とは何であったか。そしてどこに向かってい るのか」（207 頁）を探求したものが，本書である。編者である田畑伸一郎，末澤恵美を始め， 山田哲也, 角田安正, 岡奈津子, 服部倫卓, 廣瀬陽子, 岩下明裕の合計 8 名が執筆に参加し, それぞれの専門領域から CIS の歴史を振り返りつつ，分析を加えている。

通常, この種の書物では, 各分野の専門家がそれぞれの知識と情報を駆使して立場を述べ, 個々の見解の相違や相反する思想的位置をそのままに，包括的に単一の著作にまとめることが 多い。しかし本書ではCISを，まず序章で述べられているように，「ソ連邦の平和的解体と事 後処理といら歴史的使命をCIS は立派に果たした」として，「極めてポジティブな潜在力を 持っている」ものとして捉えており（28-29頁），この姿勢は全執筆者を通して一貫している。

ほぼ何の準備もなく突然誕生した国際組織を，わずか 10 年経過の時点で総括することは, なかなか困難な作業である。「CIS を全体として扱った研究書は世界でも多くはない」（208 頁） といら状況の中で, 8 名もの専門家の意思を統一し, CIS を積極的存在として描き出そうとし た本書の果敢な試みを，評者は高く評価したい。目次構成を，章立ての他に「位相」「基線」「変 異」「展開」として組み立てていることも，説得力を増している。

日本人にとって, 連邦制度, 国家連合などの組織を理解することは容易ではないが，その一 因は日本語そのものにあるのかもしれない。本来のアメリカ合州国は合衆国として定着してし まい, ソヴィエト同盟もソヴィエト連邦として呼び慣らされた。最近でも，EUを欧州連合と 
定訳化したことに異議が出されている。CIS は独立国家共同体だが，第 2 章で指摘されるよう に, 同じ共同体（コモンウェルス）を，日本ではイギリス連邦と訳している。その意味でCIS を，国際法の立場から「国際行政連合」と位置づける見解は興味深い（41 頁）。また，大英帝 国崩壊の産物としてのコモンウェルス（英連邦）と，ソ連邦崩壊の産物としてのCIS という 比較の視点 (45 頁) も, 歴史的解釈として理解できる。同様の解釈に立てば, 暴力革命によっ て成立したソ連邦と,「平和裡に法的プロセスを経て」成立したCIS との比較も成り立ちらる (29 頁)。

経済分野は, CIS 存在意義の一つであり, 求心力であったことが第 3 章で示されている。多 くの試みが為されたが，結局は旧ソ連邦の経済空間の解体を押し止められなかった。安全保障 の分野でも, 事情は似ている。第 4 章では, 集団安全保障条約や平和維持軍を例に, 軍事的統 合が成功しなかったことが説明される。二つの章の分析からは, ロシアの存在の大きさが改め て浮き彫りとなる。ロシアが主導する経済統合, ロシアを中心とする軍事統合は, かつての連 邦復活を思い起させるものとして独立を獲得した各国からの不信を招き，失敗に終わった。

一時期ほどではないが，「近い外国」はロシア外交にとって，依然重要な概念である。第 5 章では，国籍法や同胞法の立法を吟味することで，そもそもロシア人とは誰なのかについて， 問題提起している。ソ連邦内のロシア人が，ロシア人としてょりもソヴィエト人としてのアイ デンティティを強く持っていたことが， ロシア・ソヴィエト共和国の重層性につながるとの指 摘は重要である（101-102頁)。つまり，ロシア共和国はロシア人のものであるとの意識が弱 かったために，連邦崩壊後に国籍や同胞概念について深刻な喪失感を持ったといら。

CIS 内部に打稼々な統合や協力の動きとして, 第 6 章ではロシアとベラルーシの連合国 家を，第 7 章では反ロシアの対抗軸として見做されることが多いGUUAM を検証している。 連合国家については，名称や構想ばかりが先走り内実が伴っていないこと，ロシアとべラルー シ双方の指導者による政治的思惑に左右されていること, CIS 全体の統合の牽引車とは到底言 えないことが説得的に論じられる。GUUAMに関しても，誕生過程と経緯を振り返ることで, 発展といらょりはむしろ組織として衰退に向かっていることや，「参加諸国が EU 加盟や欧米 との堅固な連帯の確立を果たすまでの，当面の経済的生き残りを託すための機構」と分析され ている (156 頁)。

それでは, CIS は今後どのように展開するのか。第 8 章では, ウクライナ, コーカサス, 中 央アジアの三つの地域に分け, CIS への遠心力と求心力とに整理して考察している。しかしど の地域でも, 力学作用の基点となるのはロシアであることが明らかにされる。コーカサスを舞 台にした石油パイプライン，BTCルートをめぐる動きは，この地域を中心とした新たな国際 関係の展開を予感させる。また，遠心と求心に大きな転機をもたらしたのは 9.11 同時多発テ 口事件であった。特に中央アジアにおいて, 史上初めてアメリカ軍が駐留することになった衝 撃は，いまだに記憶に新しい。19世紀のグレイト・ゲームを引き合いに出すまでもなく，元 来中央アジアの地政学的重要性は今更強調するまでもない。今後, 中央アジアが，「自国の主 体性を高め，世界へ能動的に関わっていく重要な場の1つとして予見」されるのは間違いない (184 頁)。と同時に，その将来が極めて予測不可能であることも事実である。

このように見てくると，CIS が EUのような国際機関と異なる最大の特徵は，ただ一国とし て圧倒的な影響力を持つロシアの存在である。ロシア以外の国を抜きにしたCIS は考えられ ても，その逆はあり得ない。第 9 章では，ロシアにとっての CIS の意味について，国際法学 
者の認識，機構，統合を鍵として分析している。モスクワにとって現在のロシア連邦は，「あ る意味で『縮小したソ連邦』に過ぎない」のは事実であろう（185 頁）。そもそもロシアが旧 ソ連邦諸国を指して「近い外国」などという言葉を用いること自体，こうした雲囲気や意識を 如実に表しているとも言える（そして名指しされた国が，「近い外国」といら言葉に露骨に嫌 悪感を示すこともまた，帝国意識を捨て切れないロシアとの意識断絶を証明している)。

はしがきにおいて,「本書では, 結論や展望を執筆者の共通了解として示すことをあえてし なかった」とあらかじめ宣言してあるが，冒頭で評者が指摘したよらに，CIS を肯定的に捉え る見方で本書は統一されており，それで充分であろうと考える。代わりに置かれた解題で, CIS を，「世界政府的国際関係」に抢ける「『パートナーシップ』形成のための，最初の実験の 舞台のひとつ」として意義づけているが (212 頁), 評者はここまで積極的にはCIS を捉えら れない。そもそも突然のソ連邦崩壊といら前代未聞の事件の中で, 緊急避難的に創設されたの が CIS であり，それ（CIS）を「構成する諸国が旧ソ連構成共和国であったという事実」が（186 頁), 理解の出発点であろら。歴史的経緯があるとはいえ, CIS 結成後にロシアのエリッィン 大統領が丁重に加盟を勧めたバルト諸国が，三国揃ってこれまた丁重に拒否したことは，そし てその後も決して加盟しなかったことは，CIS の本質を象徵しているように評者には思われる のである。

本書の公刊直前にグルジアではバラ革命が，続いてウクライナではオレンジ革命が成功し， CIS そのものも, 加盟各国も, さらに大きく動いている。本書で分析の対象から外れたのが, 先に触れたバルト諸国である。これまで北欧あるいは西欧一辺倒であったバルト諸国であった が，2005年 12 月，ウクライナ，グルジア，モルドヴァの CIS 加盟国，マケドニア，スロヴェ ニア，ルーマニアの旧東欧社会主義国と共に 9 力国で，キエフにおいて「民主的選択共同体」 といら新たな組織を結成したと報じられた。結成 14 年を過ぎた CIS が, 新たな段階に入りつ つあることは間違いない。さらに歳月が経って振り返る時, CIS 結成 10 年の軌跡を多面的か つ説得的に分析した本書の価値はますます上がるであろう。 